\title{
COMPARISON OF THE EFFICACY OF TWO ANTI-URIC ACID DIETS IN DALMATIAN DOGS
}

\author{
S. BIJSTER ${ }^{1}$, R. F. NICKEL ${ }^{2}$ and A. C. BEYNEN ${ }^{1 *}$ \\ ${ }^{1}$ Department of Nutrition and ${ }^{2}$ Department of Clinical Sciences of Companion Animals, \\ Faculty of Veterinary Medicine, Utrecht University, Utrecht, The Netherlands
}

(Received October 30, 2000; accepted May 17, 2001)

\begin{abstract}
Commercial anti-uric acid diets for dogs may contain insufficient protein to sustain growth and lactation. In order to investigate the efficacy of an experimental purine-free diet moderately low in protein, its effect on urinary uric acid excretion was compared with that of a commercial dog food and a commercial low-protein anti-uric acid diet. The experimental diet, commercial dog food and commercial anti-uric acid diet contained 10.0, 12.8 and $5.0 \mathrm{~g}$ crude protein/MJ metabolizable energy, respectively. Twelve Dalmatian dogs were subjected to a $3 \times 3$ Latin square study. Although the plasma uric acid concentration was significantly lower when the dogs were fed either the commercial anti-uric acid diet $(18.7 \pm 6.0 \mu \mathrm{mol} / \mathrm{l}$, mean $\pm \mathrm{SD}, \mathrm{n}=12)$ or the experimental $\operatorname{diet}(19.2 \pm 8.3 \mu \mathrm{mol} / \mathrm{l})$, when compared to the commercial dog food $(29.2 \pm 11.1 \mu \mathrm{mol} / \mathrm{l})$, no significant decrease of uric acid concentration in urine collected before the morning meal was seen. The average concentration of urinary uric acid was $60 \mu \mathrm{mol} / \mathrm{l}$. There was a significant increase in the urea:creatinine ratio in urine when the dogs were fed the experimental diet compared to the commercial anti-uric acid diet, confirming that the experimental diet contained more protein. The experimental diet lowered plasma uric acid and was relatively high in protein and thus may be suitable for use in growing and lactating dogs to prevent ammonium urate urolithiasis.
\end{abstract}

Key words: Diet, uric acid, dog

Dalmatian dogs are at increased risk for urate urolithiasis (Schaible, 1986). The composition of the habitual diet is an important determinant of the risk for urolithiasis. Prevention and dissolution of canine ammonium urate uroliths may be achieved through dietary intervention (Osborne et al., 1986; Bartges et al., 1995). The dietary approach is based on reducing the concentrations of urolith components and raising the $\mathrm{pH}$ of the urine so that existing uroliths dissolve and/or no further precipitation occurs. The excretion of uric acid is decreased by reducing the intake of its precursors, i.e. purines (Gaebler et al., 1981; Giesecke et al., 1990). By restricting protein intake, the urine formed will be less acid,

* Corresponding author: Department of Nutrition, Faculty of Veterinary Medicine, 3508 TD Utrecht, P.O. Box 80.152, The Netherlands; E-mail: a.c.beynen@vet.uu.nl; Fax: +31 (30) 2531817 
leading to a decrease in the production of $\mathrm{NH}_{4}{ }^{+}$ions in the renal tubuli. Also, less urea is formed and excreted in the urine so that there is less substrate and thus less $\mathrm{NH}_{4}{ }^{+}$formation by urease-producing microbes which are present in case of a urinary tract infection. The addition of extra sodium chloride to the diet will promote extra water intake and thereby increases the urine volume. An increase in the so-called cation-anion difference of the diet leads to alkaline urine (Osborne et al., 1986).

The anti-uric acid diet commonly used in the practice is a low-purine, lowprotein, alkalogenic diet. However, for young, growing or lactating animals such a diet may not be suitable because insufficient protein is provided. Thus, we attempted to formulate an alternative diet with moderately low protein content. The diet was purine free and contained $10 \mathrm{~g}$ protein/MJ, the protein source being casein. The combination of the level and type of protein will sustain growth. In this study we compared the alternative anti-uric acid diet with a commercial dry dog food and a commercial anti-uric acid diet. To assess the influence of the three diets on plasma urate concentrations, we used Dalmatian dogs as model because they have high urate concentrations that are known to be sensitive to dietary intervention (Gaebler et al., 1981; Giesecke and Tiemeyer, 1984; Schaible, 1986).

\section{Materials and methods}

The experimental protocol was approved by the animal experimentation committee of the Faculty of Veterinary Medicine, Utrecht University.

\section{Animals}

Twelve Dalmatian dogs were used. There were 3 males, 6 intact bitches and 3 spayed bitches, aged 1 to 14 years. The dogs belonged to 2 different breeders and were kept under their habitual conditions. None of the dogs had any history of uric-acid urolithiasis and all were clinically healthy.

\section{Experimental design and diets}

The trial had a $3 \times 3$ Latin-square design with feeding periods of 14 days. The dogs were randomly assigned to the different diet sequences. On the last day of each feeding period, blood and urine samples were collected, and the dogs were weighed.

Three complete dry diets were used. A commercial dog food was used as a reference diet (Kiddo adult croc, Edward Baker Petfoods, Veghel, The Netherlands). For 8 of the 12 dogs this diet was their habitual diet. When assuming that the diet consisted for $50 \%$ of its major ingredient, cereals, and for $20 \%$ of meat 
and meat-by-products, the dietary purine-N level was $\geq 15 \mathrm{mg} / 100 \mathrm{~g}$. The commercial anti-uric acid diet used was Hill's canine prescription diet u/d (Hill's Pet Nutrition Inc., Topeka, Kansas, USA). The diet contained rice and corn as major ingredients. When assuming that rice and corn in a $1: 1$ ratio made up $50 \%$ of the diet, the dietary purine- $\mathrm{N}$ level was $\geq 5 \mathrm{mg} / 100 \mathrm{~g}$ (Clifford and Story, 1976). The ingredient composition of the experimental diet was as follows $(\mathrm{g} / \mathrm{kg})$ : casein, 189; glucose, 243; corn oil, 34; tallow, 135; corn starch, 243; cellulose, 41; calcium carbonate, 27; di-sodium phosphate, 41; potassium chloride, 14; magnesium carbonate, 3; trace element premix, 14; vitamin premix, 16. The composition of the premixes has been described elsewhere (Stroucken et al., 1996). The pelleted casein-containing diet was formulated so as to be purine-free and alkalogenic, and have a protein content of $10 \mathrm{~g} / \mathrm{MJ}$ metabolizable energy, which was twice as high as that of the commercial anti-uric acid diet (Table 1). The dogs were fed twice daily and had free access to water. The dogs were fed according to their calculated maintenance energy requirements, i.e. $560 \mathrm{~kJ} / \mathrm{kg}^{0.75}$.day. Prior to the experiment, the energy density of the diets was calculated on the basis of the guaranteed analysis panel of the commercial diets or ingredient composition of the experimental diet. Table 1 shows the energy densities as based on chemical analysis.

Table 1

Analysed composition and calculated protein: energy ratio of the three diets

\begin{tabular}{lccc}
\hline & Reference diet & $\begin{array}{c}\text { Commercial anti-uric } \\
\text { acid diet }\end{array}$ & Experimental diet \\
\hline Dry matter, \% & 92.4 & 93.9 & 88.6 \\
Crude protein, \% & 21.6 & 8.9 & 16.3 \\
Crude fat, \% & 14.8 & 17.3 & 16.5 \\
Crude fiber, \% & 2.4 & 2.6 & 2.8 \\
Ash, \% & 4.9 & 2.5 & 6.0 \\
Energy ${ }^{1}, \mathrm{MJ} / 100 \mathrm{~g}$ & 1.69 & 1.79 & 1.64 \\
Protein, g/MJ & 12.8 & 5.0 & 10.0 \\
\hline
\end{tabular}

${ }^{1}$ Carbohydrate content was calculated as residual fraction. Metabolizable energy in the diets was assessed using the following conversion factors: crude protein $=17 \mathrm{~kJ} / \mathrm{g}$; crude fat $=37 \mathrm{~kJ} / \mathrm{g}$ and carbohydrates $=16 \mathrm{~kJ} / \mathrm{g}$

\section{Collection of samples}

On the last day of each period, prior to feeding, the owner collected a urine sample in a beaker. On the same day, 5 hours after the morning meal, the first author took blood samples from the jugular vein and collected them into heparinized tubes. The blood and urine samples were taken to the laboratory. Blood was centrifuged (15 min, $3000 \mathrm{rpm}$ ) and plasma was collected and stored at $-18^{\circ} \mathrm{C}$ until analysis as were the urine samples. 


\section{Chemical analysis}

Immediately after completion of the experiment, uric acid, urea and creatinine in urine were measured by the use of a commercial test combination (Roche, Roche Diagnostics, Basle, Switzerland) and so was plasma uric acid. The $\mathrm{pH}$ of the urine was measured after thawing the frozen samples and prior to extraction of the sediment with $\mathrm{Na}_{2} \mathrm{Bo}_{3}\left(0.15 \mathrm{M}\right.$, pH 9) at $100{ }^{\circ} \mathrm{C}$ for $10 \mathrm{~min}$. Uric acid in the clear solution was measured with the commercial test combination. Diet samples were subjected to the Weende analysis.

\section{Statistical analysis}

The data were statistically evaluated using the paired Student's $t$-test. The level of statistical significance was preset at $\mathrm{p}<0.05$.

\section{Results}

There were no significant body weight changes during the trial. However, the dogs tended to loose weight when the commercial anti-uric acid diet was given (average weight loss was $0.3 \mathrm{~kg}$ ), and to gain weight when fed the experimental diet (average weight gain was $0.6 \mathrm{~kg}$ ).

\section{Table 2}

Plasma and urine values of the dogs as affected by the commercial anti-uric acid diet and the experimental diet

\begin{tabular}{lccc}
\hline & $\begin{array}{c}\text { Values when fed } \\
\text { the reference diet }\end{array}$ & $\begin{array}{c}\text { Change } \\
\text { after feeding } \\
\text { the commercial } \\
\text { anti-uric acid diet }\end{array}$ & $\begin{array}{c}\text { Change } \\
\text { after feeding } \\
\text { the experimental } \\
\text { diet }\end{array}$ \\
\hline $\begin{array}{l}\text { Urine } \mathrm{pH} \\
\text { Plasma uric acid, } \mu \mathrm{mol} / 1\end{array}$ & $\begin{array}{c}6.0 \pm 0.5 \\
\text { Urinary uric acid, } \mu \mathrm{mol} / 1\end{array}$ & $+0.47 \pm 0.82$ & $+0.25 \pm 0.59$ \\
$\begin{array}{l}\text { Urinary uric acid: } \\
\text { creatinine ratio, } \mu \mathrm{mol} / \mu \mathrm{mol}\end{array}$ & $0.4 \pm \pm 0.4$ & $-10.6 \pm 7.1^{*}$ & $-10.0 \pm 7.1^{*}$ \\
$\begin{array}{l}\text { Urinary urea: } \\
\text { creatinine ratio, } \mu \mathrm{mol} / \mu \mathrm{mol}\end{array}$ & $51.8 \pm 9.5$ & $-0.5 \pm 53.6$ & $-7.8 \pm 49.0$ \\
\hline
\end{tabular}

Results are expressed as means \pm SD for $12 \mathrm{dogs} ;{ }^{*}$ Significant change: $\mathrm{p}<0.05$

Table 2 shows that there was a significant decrease in the plasma concentration of uric acid when the dogs were fed either the commercial anti-uric acid diet or the experimental diet when compared with the reference diet. There was no statistically significant diet effect on the urinary concentration of uric acid and 
on the uric acid:creatinine ratio. The increase in the urinary $\mathrm{pH}$ when the dogs were fed either the commercial anti-uric acid diet or the experimental diet was not significant. The urinary urea:creatinine ratio dropped when the dogs were fed the commercial anti-uric acid diet versus either the reference or experimental diet.

\section{Discussion}

The aim of this study was to test whether it is possible to formulate an anti-uric acid diet that is not severely restricted in protein. There was a significant increase in the urea:creatinine ratio in the urine when the dogs were fed the experimental diet when compared with the commercial anti-uric acid diet. This confirms that the experimental diet provided more protein.

The results confirm previous studies in that diet can affect plasma uric acid concentrations in dogs (Gaebler et al., 1981; Giesecke et al., 1990). Irrespective of the diet fed, the plasma uric acid concentrations of the dogs were low when compared with published values for Dalmatian dogs fed a purine-free diet (Gaebler et al., 1981). Thus, even the concentrations seen when the commercial dog feed was fed were relatively low, indicating that this feed is low in purines. A linear relation has been found between purine intake and the urinary uric acid excretion, but on purine-free diets the excretion is based on endogenous purine catabolism (Giesecke and Stangassinger, 1990). The likeliness that the commercial dog food was low in purine would explain why the commercial and experimental anti-uric acid diet did not further decrease urinary uric acid excretion. Unfortunately, purine analysis of the three diets was not performed. In our study we took urine spot samples whereas in other studies 24-hour samples were taken (Schaible, 1986). Possibly, a diet-induced decrease in urinary uric acid is less profound in pre-feeding urine.

Although there was no diet effect on the uric acid concentration in morning urine, the two anti-uric acid diets were equally effective as to plasma uric acid lowering. The experimental anti-uric acid diet was relatively high in protein and thus may be suitable for growing and lactating animals to prevent ammonium urate urolithiasis.

\section{Acknowledgements}

We thank Mr. and Mrs. Verhoorevoort (Zandvoort) and Mr. van Nierop and Mrs. de Boer (Lambertschaag) for placing the dogs at our disposal and for taking care of them during the experiment. Thanks are due also to Inez Lemmens for expert analytical assistance. 


\section{References}

Bartges, J. W., Osborne, C. A., Felice, L. J., Allen, T. A., Brown, C., Unger, L. K., Koehler, L. A., Bird, K. A. and Chen, M. (1995): Diet effect on activity product ratios of uric acid, sodium urate and ammonium urate in urine formed by healthy Beagles. Am. J. Vet. Res. 56, 329-333.

Clifford, A. J. and Story, D. L. (1976): Levels of purines in foods and their metabolic effects in rats. J. Nutr. 106, 435-442.

Gaebler, S., Maier, J., Tiemeyer, W. and Giesecke, D. (1981): Über den einfluss von Diäten mit definiertem Nucleinsäuren und Puringehalt auf den Harnsäurespiegel im Blutplasma von Dalmatiner-Hunden. Zbl. Vet. Med. A 28, 494-503.

Giesecke, D. and Stangassinger, M. (1990): Einflüsse purinreicher Ernährung auf die renale und extrarenale Exkretion von Purinkataboliten bei Dalmatiner-Hunden. Z. Ernährungswiss. 29, 208-218.

Giesecke, D. and Tiemeyer, W. (1984): Defect of uric acid uptake in Dalmatian dog liver. Experientia 40, 1415-1416.

Giesecke, D., Gallenmüller, P., Tiemeyer, W. und Gropp, J. (1990): Einflüsse purinreicher Ernährung auf Gewichtsentwicklung, Kataboliten im Blutplasma und den Harnsäuretransport von Erythrozyten - eine Modellstudie an Hunden. Z. Ernährungswiss. 29, 135-146.

Osborne, C. A., Kruger, J. M., Johnston, G. R. and Polzin, D. J. (1986): Dissolution of canine ammonium urate uroliths. Vet. Clin. North Am.: Small Anim. Prac. 16, 375-388.

Schaible, R. H. (1986): Genetic predisposition to purine uroliths in Dalmatian dogs. Vet. Clin. North Am.: Small Anim. Prac. 16, 127-131.

Stroucken, W. J. P., Van der Poel, A. F. B., Kappert, H. J. and Beynen, A. C. (1996): Extruding vs pelleting of a feed mixture lowers apparent nitrogen digestibility in dogs. J. Sci. Food Agric. 71, 520-522. 